\title{
A Variant Insulin Promoter in Non-insulin-dependent Diabetes Mellitus
}

\author{
Leann Olansky," Cris Welling, Stephen Giddings, Stuart Adler, Raymond Bourey, Gary Dowse, ${ }^{*}$ Susan Serjeantson," \\ Paul Zimmet, ${ }^{*}$ and M. Alan Permutt \\ Metabolism Division, Department of Internal Medicine, Washington University Medical School, St. Louis, Missouri 63110; *Department \\ of Internal Medicine, University of Oklahoma, Oklahoma City, Oklahoma 73190; 'Department of Internal Medicine, International \\ Diabetes Institute, Caulfield South, Victoria 3162, Australia; and ${ }^{\S}$ Department of Internal Medicine, John Curtin School of Medical \\ Research, Canberra, Australian Capital Territory 2601, Australia
}

\section{Abstract}

To test the hypothesis that alterations in regulatory regions of the insulin gene occur in a subset of patients with non-insulindependent diabetes mellitus (NIDDM), the promoter region was studied by polymerase chain reaction (PCR) amplification directly from genomic DNA, followed by high-resolution polyacrylamide gel electrophoresis under nondenaturing conditions. By using this method a previously identified HincII polymorphism (GTTGAC to GTTGAG at position -56) in American Blacks was readily detected, indicating that single base changes could be observed. In the course of screening the insulin promoter from 40 American Black subjects with NIDDM, an apparent larger allele was found in two individuals. Both patients were shown to have in addition to a normal allele, a larger allele containing an 8-bp repeat, TGGTCTAA from positions -322 to -315 of the insulin promoter.

To facilitate rapid screening for the 8-bp repeat, a high-resolution agarose gel electrophoretic analysis was adopted. DNA from American Black NIDDM subjects $(n=100)$ and nondiabetic subjects $(n=100)$ was PCR amplified and analyzed. The 8-bp repeat was present in five NIDDM subjects, and one nondiabetic subject. DNA from Mauritius Creoles, also of African ancestry, was analyzed, and the 8-bp repeat was present in 3 of 41 NIDDM subjects, and 0 of 41 nondiabetic subjects. Analysis of glucose metabolism in three presumed normal sibs of an NIDDM patient with an 8-bp repeat revealed that one sib had overt diabetes, and two sibs were glucose intolerant, but there was no consistent segregation of the insulin promoter variant with the diabetes phenotype. The variant promoter was not present in 35 Caucasian NIDDM patients or in 40 Pima Indians.

To test the biological consequences of the 8-bp repeat sequence in the insulin promoter, a normal and variant promoter were subcloned into a luciferase plasmid, and reporter gene activity assessed by transient transfection into mouse insulinoma ( $\beta$ TC1) and hamster insulinoma (HIT) cells. The promoter activity of the variant allele was found to be reduced to $37.9 \pm 10.3 \%$ of the activity of the normal promoter in HIT cells $(P<0.01, n=4)$, and $49.1 \pm 6.4 \%$ in $\beta$ TC1 cells $(P<0.01$, $n=6)$. These data thus suggest that a naturally occurring vari-

Address reprint requests to Dr. Permutt, Metabolism Division, Washington University School of Medicine, 660 South Euclid Avenue, Box 8127, St. Louis, MO 63110.

Received for publication 8 October 1991 and in revised form 11 December 1991.

J. Clin. Invest.

(C) The American Society for Clinical Investigation, Inc.

$0021-9738 / 92 / 05 / 1596 / 06 \$ 2.00$

Volume 89, May 1992, 1596-1602 ant of the insulin promoter may contribute to the diabetes phenotype in 5-6\% of Black NIDDM patients. (J. Clin. Invest. 1992. 89:1596-1602.) Key words: human insulin promoter • insulinoma cells - non-insulin-dependent diabetes mellitus • polymerase chain reaction - reporter gene activity

\section{Introduction}

Structural gene mutations have been observed in a small number of individuals with non-insulin-dependent diabetes mellitus (NIDDM) ${ }^{1}$ (1). These mutations have been associated with either failure of conversion of proinsulin to insulin, or a biologically defective insulin resulting in hyperinsulinemia. Most individuals with NIDDM, however, have insulin resistance and islet $\beta$-cell insulin production is not sufficient to meet enhanced insulin demand (2). Diminished insulin production would more likely result from decreased transcription of the gene, perhaps due to variations in the insulin promoter region, or to alterations in the genes that regulate transcription of the insulin gene. These transcriptional mutations, if they exist, would be difficult to detect since human islet tissue is not readily available for analysis. Because DNA is easily obtained from subjects with NIDDM, a number of studies have used DNA polymorphisms at the insulin locus to evaluate this possibility.

A hypervariable region of DNA, composed of variable numbers of tandem repeats resulting in many different sized alleles, is located $\sim 375$ base pairs (bp) upstream from the transcription initiation site of the insulin gene (3). Initial reports of a positive association of a large class 3 allele with NIDDM were not confirmed in later studies of larger racially uniform populations (see reference 4 for review). Linkage analysis in families with maturity onset diabetes of the young $(5,6)$, the autosomal dominant subtype of NIDDM, and in more typical Northern European Caucasian (7) and American Black (8) NIDDM families, concluded that there was no linkage of the insulin gene and NIDDM, and that insulin gene defects are not a major factor predisposing to NIDDM. If the disease were polygenic, however, this interpretation may not be correct.

Evidence has been presented that NIDDM is a complex metabolic disorder unlikely to be the result of a single gene defect $(9,10)$. Because of the limitations of restriction fragment length polymorphism RFLP analysis in populations and linkage analysis in families when considering polygenic and multifactorial diseases such as NIDDM (11), the current study was undertaken to evaluate insulin genes directly at the genomic

1. Abbreviations used in this paper: NIDDM, non-insulin-dependent diabetes mellitus; PCR, polymerase chain reaction; RFLP, restriction fragment length polymorphism; SSCP, single-strand conformational polymorphism. 
level. Two new techniques made this analysis possible. The first consists of amplification of specific regions of the insulin gene directly from genomic DNA by the polymerase chain reaction (PCR), followed by separation of the amplified alleles by a highly sensitive electrophoretic method $(12,13)$. This method involves incorporation of labeled primers into the amplified DNA fragment during PCR, followed by denaturation of the two strands, and electrophoresis on nondenaturing gels. The mobility of the fragments under these conditions is determined by base composition as well as size (single-strand conformational polymorphism [SSCP]), and under appropriate conditions single base changes can be detected. Using these methods we found a variant of the human insulin promoter which appears to have diminished promoter activity, and may be associated with NIDDM in Blacks.

\section{Methods}

Subjects. All American Black and Caucasian subjects were recruited from the Washington University Medical School Clinics or from the Diabetes Registry, and signed consent was obtained according to a protocol approved by the Human Studies Committee. Pima Indian DNA was obtained from Drs. Steven Lillioja and Clifton Bogardus, National Institutes of Health, Phoenix, AZ, as part of a study to evaluate candidate genes for diabetes susceptibility. DNA from Mauritius Creoles was obtained through the 1987 Mauritius Noncommunicable Disease and Risk Factor Prevalence Survey. Mauritius is an island in the southwestern Indian Ocean east of Madagascar. Creoles are of African and Malagasy ancestry with various amounts of Caucasian and to a lesser extent Indian genetic admixture (14). NIDDM was defined as described (14) by this group. All Washington University patients with NIDDM were identified by personal history and medical records, and plasma glucose was measured on the sample obtained for DNA. Control subjects were defined as patients $>35 \mathrm{yr}$ of age, without a personal or family history of diabetes, and confirmed to have a fasting plasma glucose $<115 \mathrm{mg} / \mathrm{dl}$, or a postprandial plasma glucose $<140 \mathrm{mg} / \mathrm{dl}$. A positive family history for the American Blacks was defined as diabetes diagnosed by history in grandparents, parents, uncles, aunts, sibs, or offspring of the probands.

PCR amplification of genomic DNA. Polymerase chain reactions were carried out in 10- $\mu$ l volumes with $25 \mathrm{ng}$ of EcoRI-digested genomic DNA, $200 \mu \mathrm{M}$ each dNTP, and $1 \mathrm{U}$ Taq polymerase (Amplitaq, Perkin Elmer/Cetus, Norwalk, CT) under standard buffer conditions (15), with $\mathrm{Mg}^{2+}$ optimized to $1.25 \mathrm{mM}$, with annealing phase $1 \mathrm{~min}$ at $64^{\circ} \mathrm{C}$, extension $1 \mathrm{~min}$ at $72^{\circ} \mathrm{C}$, and denaturation $1 \mathrm{~min}$ at $94^{\circ} \mathrm{C}$ for 30 cycles in a Perkin-Elmer Thermocycler. The oligonucleotide primers, 20-25-mers chosen to contain $\sim 50 \%$ GC with $\mathrm{G}$ or $\mathrm{C}$ on the $3^{\prime}$ end, were synthesized on an model 380B DNA synthesizer (Applied Biosystems, Inc., Foster City, CA) by the Washington University Protein Chemistry Lab, ethanol-precipitated, and used without further purification. Primers used are indicated in Fig. 1.

Electrophoresis. For SSCP, the reverse primer was $5^{\prime}$ end-labeled for $45 \mathrm{~min}$ at $37^{\circ} \mathrm{C}$ in a $25-\mu \mathrm{l}$ reaction containing $25 \mathrm{pmol}$ primer, T4 polynucleotide kinase buffer, $40 \mu \mathrm{Ci}\left[\gamma-{ }^{32} \mathrm{P}\right] \mathrm{ATP}$ at $5,000 \mathrm{Ci} / \mathrm{mmol}$ (Amersham Corp., Arlington Heights, IL), and $5 \mathrm{U}$ T4 polynucleotide kinase before the PCR reaction. Reaction products were then electrophoresed on $8 \%$ or $10 \%$ acrylamide $89 \mathrm{mM}$ Tris, $89 \mathrm{mM}$ borate, $2 \mathrm{mM}$ EDTA, pH8 (TBE) gels at $40 \mathrm{~W}$ for $5 \frac{1}{2} \mathrm{~h}$ at room temperature as described by Orita et al. $(12,13)$. Although $10 \%$ glycerol was used in some SSCP gels, its presence was not necessary to observe the variants described in this report. Screening gels were 4\% NuSieve (3:1) in TBE buffer, stained with ethidium bromide.

Cloning and sequence analysis. The insulin promoter variants were subcloned into M13 and/or Bluescript plasmids by standard methods (16). Sequencing of the fragments subcloned in M13 was by the dideoxy chain termination method using Sequenase (USP) and $\left[{ }^{35} \mathrm{~S}\right]-$ dATP (Amersham Corp.) with either the universal M13 primer or synthetic oligonucleotides as described by the manufacturer. Sequencing directly from genomic DNA was as previously described (17).

Transient transfections and luciferase assays. $\beta \mathrm{TCl}$ (mouse insulinoma) $(18,19)$ and HIT (hamster insulinoma) $(20)$ cells were grown and passaged in DME with $16.5 \mathrm{mM}$ glucose (5.5 mM glucose DME with glucose added to $16.5 \mathrm{mM}$ ) supplemented with $10 \%$ FBS. Cells were plated at a density of $2 \times 10^{6}$ cells per $100 \mathrm{mM}$ dish $2 \mathrm{~d}$ before transfection. Approximately $4 \mathrm{~h}$ before transfection, cells were refed. Each plate received a Ca-phosphate solution containing $10 \mu \mathrm{g}$ of an insulin-luciferase fusion plasmid plus $10 \mu \mathrm{g}$ of salmon DNA carrier (21). After an overnight incubation in $5 \% \mathrm{CO}_{2}$, cells were shocked for 2 min with $20 \%$ glycerol in DME, washed, and refed. Cells were harvested in $700 \mu \mathrm{l}$ of $50 \mathrm{mM}$ Tris-2 ( $\mathrm{N}$-morpholino)ethane sulfonic acid (MES) (pH 7.8), 1 mM DTT, $1 \%$ Triton X-100, 48 hrs after glycerol shock. Luciferase activity was assayed using a Monolight model 2010 instrument (Analytical Luminescence Laboratory, San Diego, CA), primed with $1 \mathrm{mM}$ D-luciferin, and integrating light units over $10 \mathrm{~s}$. Reactions $(300 \mu \mathrm{l})$ contained $50 \mathrm{mM}$ Tris-MES (pH 7.8), $10 \mathrm{mM}$ $\mathrm{Mg}(\mathrm{OAc})_{2}, 2 \mathrm{mM}$ ATP, $333 \mu \mathrm{M}$ D-luciferin, $167 \mu \mathrm{M}$ DTT, and $0.17 \%$ Triton X-100.

Results obtained are presented as light minus background \pm SEM from multiple identical plates for each of several experiments. Although expression levels changed for each experiment, variation

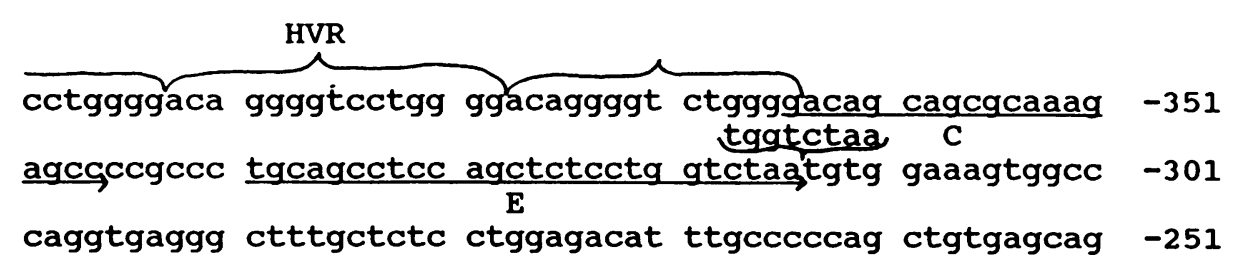

$\begin{array}{cc}\text { ggacaggtct ggccaccggg cccctggtta agactctaat gacccgetgg } & -201 \\ \text { F } & \text { D } \\ \text { tcctgaggaa gaggtgctga cgaccaagga gatcttccca, cagacccagc } & -151 \\ \text { A } & \\ \text { accagggaaa tggtccggaa attgcagcct cagcccccag ccatctgccg } & -101\end{array}$

accagggaaa tggtccggaa attgcagcct cagcccccag ccatctgccg -101

cccaggccet aatgggccag gcggcagggg ttgacaggta

ggggagatgg gctctgagac tataaagcca gcgggggccc agcagccctc

agccctccag gacaggctgc afcagaagag gccatcaagc aggtctgttc
Figure 1. Sequence of the human insulin gene promoter region including a portion of the hypervariable region, composed of 14-15-bp tandem repeats -51 (3), indicated $(H V R)$. The PCR primers, described in Methods, and their orien-

-1 tations are indicated by arrows. The HincII RFLP at -56 , and the 8-bp re+50 peat (TGGTCTAA) at -315 , are also indicated. 
among identical plates within an experiment averaged $<10 \%$ (see Table II). Because of the inherent reproducibility of these results, the relatively low signals, and the possibility of interference from inclusion of other plasmids, additional plasmids based on another reporter system for internal standardization of transfection efficiency were not included.

Luciferase reporter plasmids. Luciferase plasmids are derivatives of pSV2A $\Delta 5^{\prime} \mathrm{L}$ (22), with the insulin promoters replacing the SV40 sequences located $5^{\prime}$ to the luciferase gene. Insulin promoter sequences are from -366 to +42 and are derived from either the normal allele or the allele containing the 8-bp repeat.

Clinical studies. Oral glucose tolerance tests were performed with $75 \mathrm{~g}$ of glucose according to a standard protocol. Hyperglycemic clamps were performed to assess the insulin response to a constant plasma glucose as previously described (23). Plasma glucose concentration was measured by an automated glucose oxidase method (Beckman Instruments, Inc., Fullerton, CA). Serum insulin concentration was measured by radioimmunoassay.

Statistical analysis. All experimental data are expressed as mean \pm standard error of mean (SEM). Statistical analyses were performed using paired or unpaired two tailed Student's $t$ tests or $\chi^{2}$ analysis as appropriate. Probability values $P<0.05$ were considered significant. Calculations were performed using the CLINFO Data Analysis System of Washington University (General Clinical Research Center RR00036) supported by the Division of Research of the National Institutes of Health.

\section{Results}

Confirmation that SSCP can detect single base changes in the insulin promoter. To confirm that PCR amplification of the promoter region of the insulin gene and electrophoresis by SSCP would permit detection of differences, a known polymorphism was first studied. A Hincll site at positions -61 to -56 (GTTGAC) had been shown to be absent in $40 \%$ of American Blacks (24). We sequenced the promoter region directly from genomic DNA of several individuals previously typed at this locus, and determined that HincII minus alleles had the sequence GTTGAG. PCR amplification of a number of unrelated individual with ${ }^{32} \mathrm{P}$ 5'-end-labeled primer 7096(A) at position -183 and reverse primer 10594 (B) at position +42 , indicated in Fig. 1, and electrophoresis under SSCP conditions resulted in clearly identifiable alleles positive or negative for the HincII site (Fig. 2).

$A$ variant of the insulin promoter, detected by screening with $P C R-S S C P$. Analysis of the insulin promoter from -183 to +42 of 20 American Black NIDDM patients (40 alleles) by PCR-SSCP and by direct genomic sequencing revealed only the HinclI polymorphism at position -56 . Next the promoter

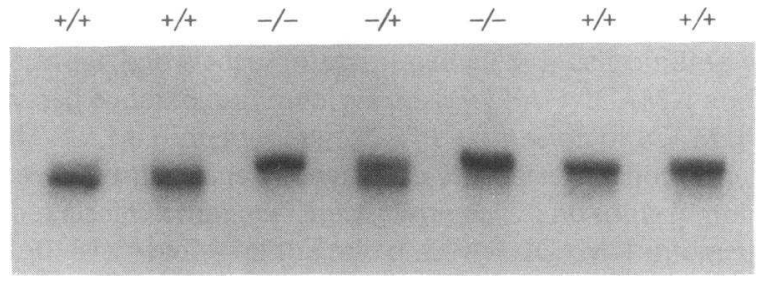

Figure 2. A 225-bp fragment of the human insulin promoter (-183 to +42) was PCR-amplified from genomic DNA of a number of individuals with primers $A\left({ }^{32} \mathrm{P}\right.$ end-labeled) and $\mathrm{B}$ as in Fig. 1, and electrophoresed by SSCP as described in Methods. "+" refers to the presence of a HinclI site at position -56 (GTTGAC), and "-" to the absence of the site (GTTGAG).

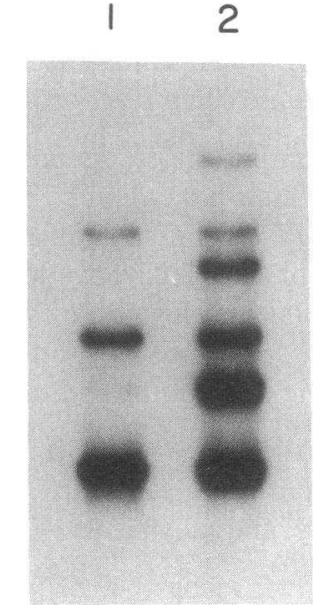

Figure 3. Analysis of the insulin promoter from positions -365 to -164 by PCRSSCP from two individuals, lanes 1 and 2 . Three bands are seen in lane 1 . These same three bands are also seen in lane 2 , as well as three apparently larger corresponding bands.

from -365 to -164 was evaluated by PCR-SSCP with primer 10593 (C) and reverse primer 10595(F), as shown in Fig. 1. The SSCP pattern of a normal individual is seen in Fig. 3, lane 1 . Only one of the primers was labeled, and thus only one major band would be predicted. The two less intense bands represent minor conformations of this same amplified fragment. In the first analysis of 20 individuals, a single variant pattern was found as shown in Fig. 3 (lane 2), which suggested the presence of a normal and a larger allele in one individual. Analysis of DNA from 20 additional NIDDM patients revealed another person with an apparent larger allele.

Molecular basis for the variant promoter. The molecular basis for this variant insulin promoter was defined by subcloning the amplified promoter of both individuals in M13 and determining the sequences. Both patients were heterozygous for a normal and a larger allele. Examples of the sequences from one patient are seen in Fig. 4. Initially the sequences, reading from $5^{\prime}-3^{\prime}$ were identical, until the 8 -bp sequence

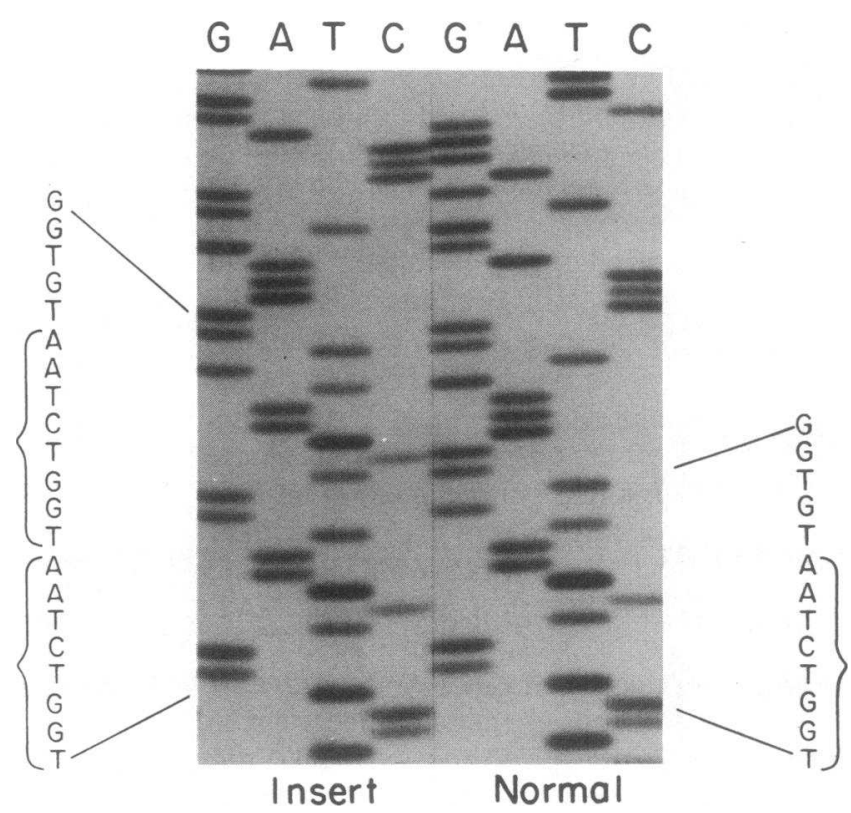

Figure 4. Sequences of the normal and larger (insert) alleles from the insulin promoter of the NIDDM patient shown by PCR-SSCP in Fig. 3 , lane 2 . The 8 -bp tandem repeat is indicated by brackets. 


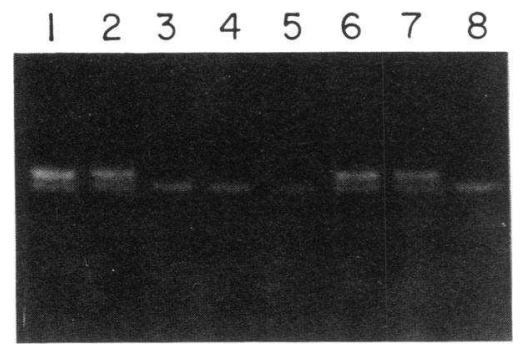

Figure 5. Analysis of the insulin promoter of eight individuals from positions -340 to -198 by PCR amplification using primers $\mathrm{E}$ and $\mathrm{D}$ (Fig. 1) from genomic DNA, followed by electrophoresis on a $4 \%$ NuSieve (3:1) agarose gel in TBE buffer, and stained with ethidium bromide. Individuals in lanes $1,2,6$, and 7 have one normal and one larger allele, while those in lanes 3-5 and 8 are homozygous for normal alleles.

TGGTCTAA was repeated in tandem in the larger allele. This same 8-bp repeat was present in other patients, as confirmed by sequencing a variant allele from another American Black NIDDM patient, and a Mauritius Creole patient with NIDDM (see below).

Frequency of the variant allele in three racial groups. To determine the frequency of the variant allele in populations, a more rapid analytical method was devised. Knowing that the variant was an 8-bp larger allele, we PCR-amplified a relatively small fragment of the insulin promoter $(142 \mathrm{bp})$ with primers $E$ and D (Fig. 1), and were able to separate large and small alleles on a $4 \%$ agarose (NuSieve) gel as shown in Fig. 5. This sensitive and more rapid screening method enabled us to evaluate the promoter region from 100 nondiabetic American Black individuals, and an equal number with NIDDM. As shown in Table I, the variant was present in five patients with NIDDM and one nondiabetic subject $(P=0.24)$.

Next the presence of variant alleles was evaluated in 35 Caucasian NIDDM patients and 40 Pima Indians, and none were found. Mauritius Creoles, like American Blacks, are African descendants with partial European Caucasian admixture, and with a high prevalence of NIDDM (14). We had the opportunity to determine the frequency of the variant insulin promoter in a smaller number of Mauritius Creoles, and the variant was identified in three subjects with NIDDM, but in none of the nondiabetic individuals (Table I, NS).

Clinical evaluation of the effects of the variant insulin promoter. All five of the NIDDM patients with variant insulin promoters were considered for differences in clinical characteristics. The number of subjects was small, and no obvious differences were apparent in age, age of diagnosis of diabetes, body mass index, or insulin requirements. At least three of these patients had a positive family history of NIDDM. One patient (L.M.) had a sister (S.L.) with known diabetes, and four sibs not known to have diabetes, as shown in the pedigree in Fig. 6. The sister with NIDDM (S.L.) did not have a variant insulin promoter, and thus in this family the insulin promoter variant was not necessary for diabetes. We had the opportunity to study three of the reported nondiabetic sibs (W.L., J.L., and L.P.).

The results of a 3-h oral glucose tolerance test in the three reported nondiabetic sibs of the proband are shown in Table II. The sister (L.P.), positive for the variant promoter, was found to have overt NIDDM, with a fasting plasma glucose of 302 $\mathrm{mg} / \mathrm{dl}$, and a poor insulin secretory response. The two brothers, one with two normal alleles (W.L.), and the other with a normal and variant insulin promoter (J.L.), showed virtually identical glucose responses, diagnosed as glucose intolerant by crite-
Table I. Individuals with Variant Insulin Promoters by Diabetes Status

\begin{tabular}{lcc}
\hline & \multicolumn{2}{c}{ Insulin promoter alleles } \\
\cline { 2 - 3 } & Normal & Variant \\
\hline American Blacks & & \\
$\quad$ Nondiabetic & 99 & 1 \\
$\quad$ NIDDM & 95 & 5 \\
$P=0.24$, Yates correction & & \\
Mauritius Creoles & & \\
$\quad$ Nondiabetic & 41 & 0 \\
$\quad$ NIDDM & 38 & 3 \\
\hline
\end{tabular}

$P=0.239$, Yates correction

ria of FBS $<140 \mathrm{mg} / \mathrm{dl}, 30-90 \mathrm{~min}$ glucose $>200 \mathrm{mg} / \mathrm{dl}$, and $120 \mathrm{~min}$ glucose $>140 \mathrm{mg} / \mathrm{dl}$. The insulin secretory response appeared less in J.L. relative to W.L. (total area under the curve 4,268 vs. $8,693 \mu \mathrm{U} \cdot \mathrm{min} / \mathrm{ml}$ ), suggesting either an islet $\beta$-cell defect in J.L., or that J.L. was insulin sensitive relative to his brother.

Islet $\beta$-cell function was further assessed by measuring the insulin response of the two brothers to an identical intravenous glucose challenge. Hyperglycemic clamps were performed for 3 $\mathrm{h}$ by infusing glucose to raise and maintain plasma glucose at $270 \mathrm{mg} / \mathrm{dl}(15 \mathrm{mM})$. The results of these studies (Table III) revealed that J.L. (positive for the variant promoter) had a $40 \%$ greater early phase $(0-10 \mathrm{~min})$ insulin response, but a similar late-phase (15-180 $\mathrm{min}$ ) response, and nearly identical insulin concentrations at $180 \mathrm{~min}(66 \mathrm{vs} .67 \mu \mathrm{U} / \mathrm{ml})$. JL was also apparently more insulin-sensitive than his brother as the mean glucose disposal rate for the near-steady-state $150-180 \mathrm{~min}$ pe-

Table II. Reporter Gene Activity of the Normal and Variant Insulin Promoters Transfected into Hamster (HIT) or Mouse (BTC1) Insulinoma Cells

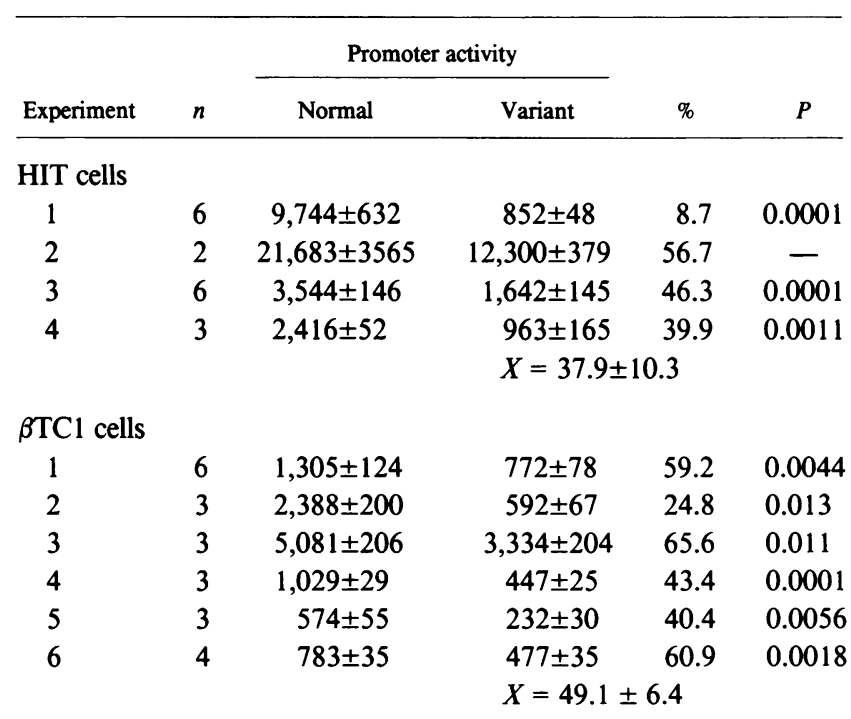

Promoter activity in light units, $X \pm \mathrm{SEM} . n$, number of plates assayed. Where $n=2, X \pm$ range. 
Table III. Glucose Metabolic Studies of Three Previously Reported Nondiabetic Members of the L.M. Family (Fig. 6).

A. Oral glucose tolerance test: plasma glucose/serum insulin

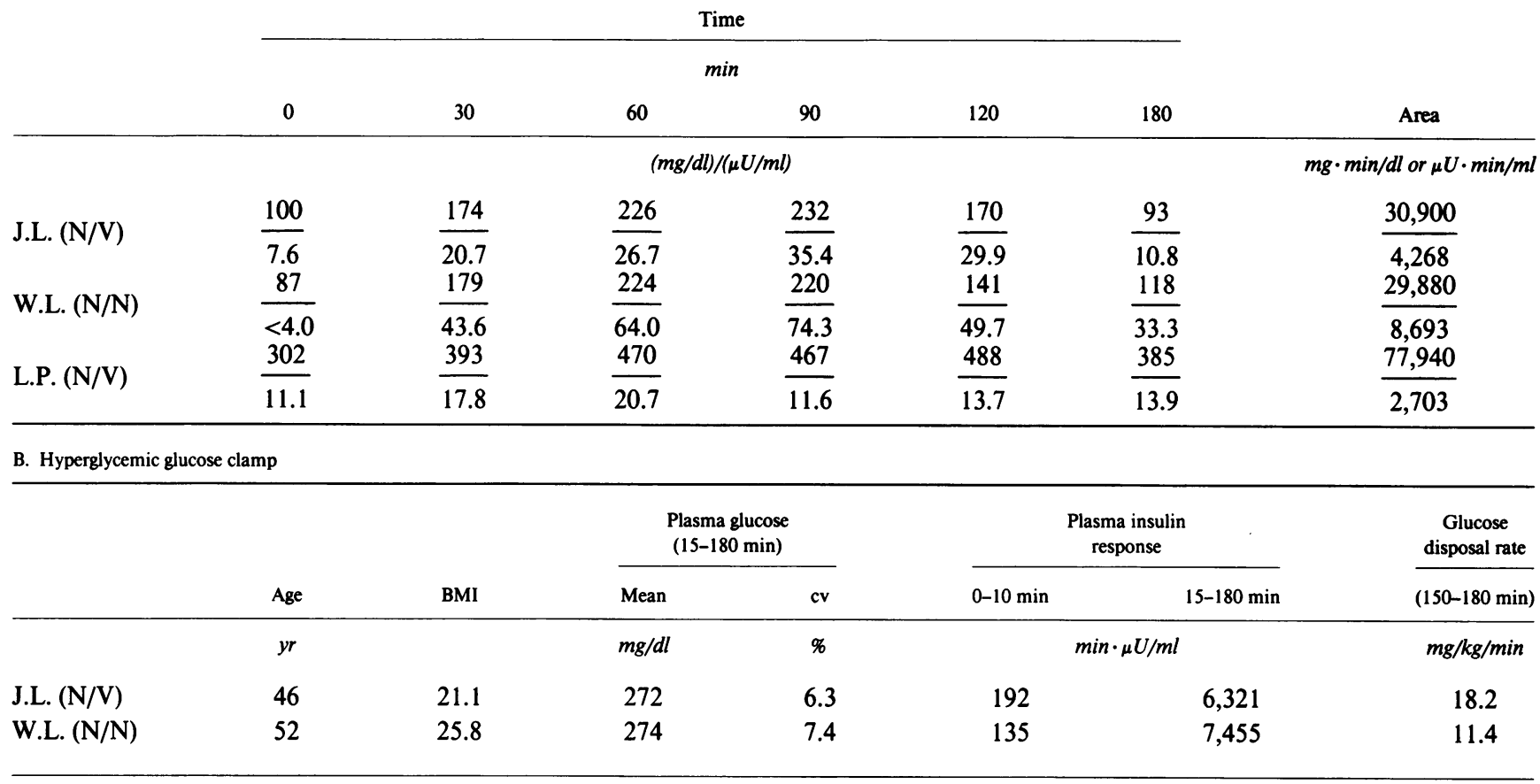

The proband L.M. was identified because she had a variant insulin promoter. Insulin promoter genotypes of her sibs are indicated: N, normal; V, variant.

riod was $60 \%$ greater at similar mean serum insulin concentrations (61 vs. $59 \mu \mathrm{U} / \mathrm{ml})$.

Promoter activity assay. To determine whether the presence of the 8-bp tandem repeat within the promoter region conferred different transcriptional activity, a reporter gene assay was developed. Both normal and insert-containing insulin promoters (from -366 to +42 ) were subcloned upstream of the firefly-luciferase coding region, and these fusion gene plasmids transfected into mouse ( $\beta T C 1)$ and hamster (HIT) insulinoma cells. Transient expression of these chimeric genes in both cell lines revealed that the variant insulin promoter had $<50 \%$ of the promoter activity of the normal allele (Table II).

\section{Discussion}

Direct genomic analysis of the insulin gene promoter from NIDDM patients revealed a previously undescribed 8-bp repeat, TGGTCTAA, $315 \mathrm{bp}$ upstream of the start of transcription of the gene. This represents the first variant insulin promoter described. The current studies defined the frequencies of the variant in four racial groups, and addressed the possible biological and clinical consequences of the variant on carbohydrate metabolism. The strategies used were $(a)$ to examine clinical phenotypes, $(b)$ perform linkage analysis in a family, along with metabolic studies on selected members, $(c)$ compare the frequencies of the variant in populations of NIDDM patients vs. controls, and $(d)$ assess promoter activity by transient expression in cultured insulinoma cells.

The clinical consequences of the variant insulin promoter are not clear from examination of the phenotypes. As only one affected allele was present in all subjects where the variant was detected, a modest effect on insulin gene transcription may have little effect, given that transcription from the normal promoter should be unaffected. The capacity to produce insulin might be altered, however, and manifested perhaps only in obese individuals with higher insulin requirements. There were no obvious differences in phenotypes of the five American Black NIDDM patients with the variant allele however.

As one of these patients had a family available for analysis, we had the opportunity to do linkage analysis and observe the possible clinical consequences of the variant (Fig. 6). This family appeared to have other genes and/or factors predisposing to NIDDM, in that one sister (S.L.) of the proband (L.W.) had NIDDM without the variant insulin promoter allele. A second sister with a variant promoter (L.P.) was found on testing to be diabetic. While this complicates the analysis, this same problem may be encountered in most families with NIDDM, if this disorder is polygenic. We attempted to assess insulin production in the two brothers, one with and the other without the variant promoter, by oral glucose tolerance tests and hyperglycemic glucose clamps. During the glucose tolerance tests, both appeared to be glucose intolerant by standard criteria. As the relationship between insulin sensitivity and $\beta$-cell function is complex and difficult to interpret, the brothers were further assessed by hyperglycemic clamps with a fixed glucose challenge. Although there were minor differences in early insulin responses, overall the responses were comparable. It has never been easy to assess insulin producing capacity in vivo (25). Both brothers are lean, whereas the diabetic sisters are obese. One might speculate that obesity and genes which promote insulin resistance may be necessary to uncover defects in insulin production. These hypotheses are difficult to test in humans, but have been addressed in experimental animal models $(26,27)$. 


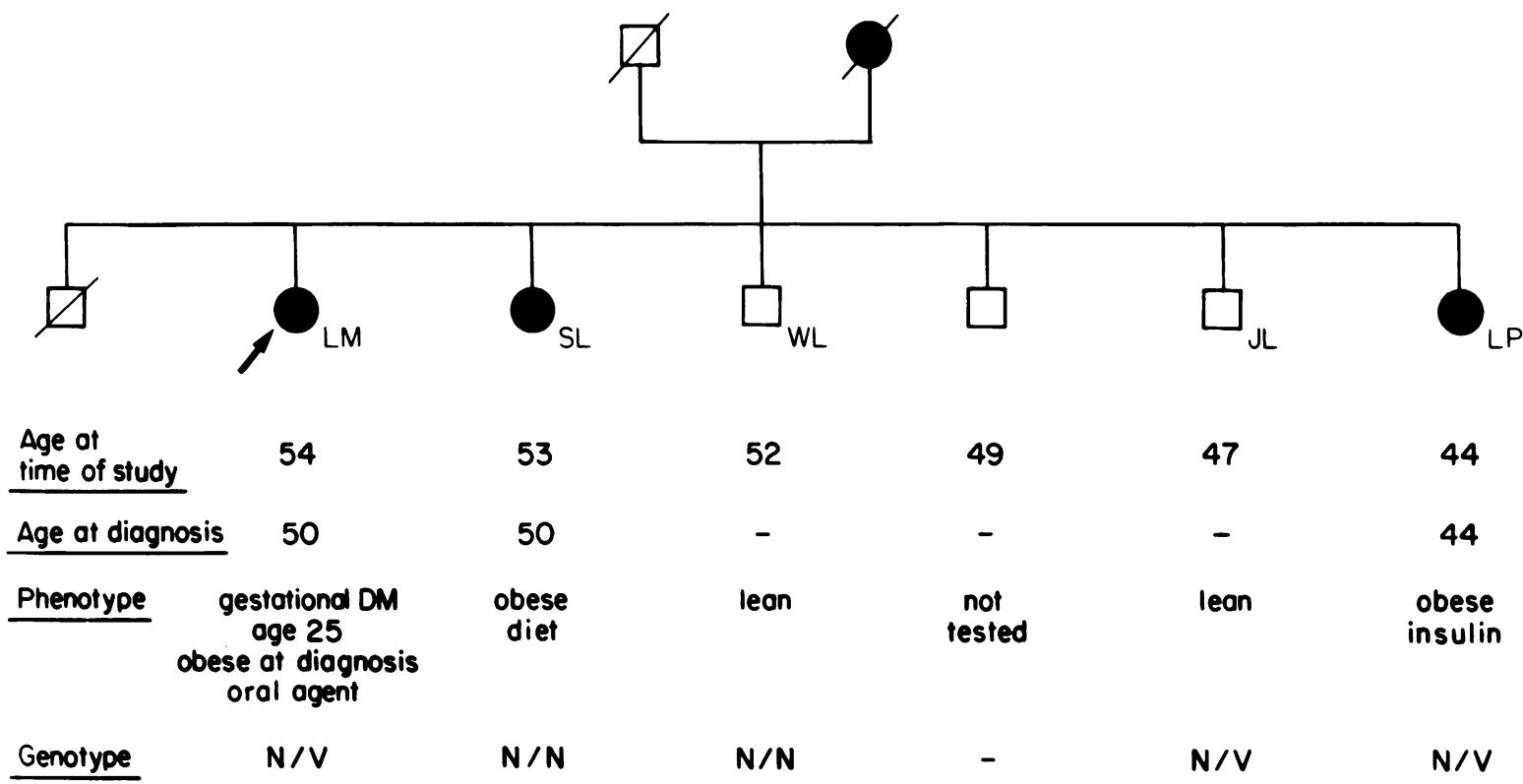

Figure 6. Patient L.M. pedigree. The proband, L.M. (arrow), was identified because she has NIDDM and a variant insulin promoter in one allele. The phenotypes and genotypes of her affected (solid) and unaffected (empty) relatives are indicated. N, normal allele; $\mathrm{V}$, variant allele.

The variant insulin promoter appeared to occur more frequently in a population of American Black NIDDM patients relative to nondiabetic controls ( $5 \%$ vs. $1 \%$, Table I), but the sample size was too small to indicate whether this apparent difference was real. The variant was not present in 70 Caucasian or 80 Pima Indian alleles. We were fortunate to have Mauritius Creole DNA available as part of another study, and found that the variant insulin promoter occurred in 3 of 41 (7.3\%) NIDDM patients. Thus the variant promoter was found only in patients of African ancestry. The frequency of the variant appeared to be more common in NIDDM subjects when both American Blacks and Mauritius Creoles were considered together (5.7\% vs. $0.7 \%, P=0.042$, Yates correction). Because of known genetic admixture with Caucasian genes (28), one might predict that the frequency of the variant promoter may be even greater in African Blacks with NIDDM. This hypothesis is currently being addressed.

Whether the variant insulin promoter affects transcription of the gene in vivo was evaluated by transient expression in cultured insulinoma cells. The results of four independent transfections in HIT cells and six transfections in $\beta \mathrm{TCl}$ cells suggested a significant reduction in promoter activity of the variant (Table II). Both HIT and $\beta$ TCl cells have been widely used to study expression of insulin genes (29-31), but these cells are imperfect models of regulated expression, being defective in insulin responses to glucose $(18,20)$. In this regard, HIT and $\beta \mathrm{TC} 1$ cells were cultured in 5,16 , and $25 \mathrm{mM}$ glucose for $48 \mathrm{~h}$ after transfections, and the results with the normal and variant promoters did not differ from those described in Table II. Nonetheless, the differences observed between the activities of normal and variant promoters in both cell types are highly suggestive, and would encourage more definitive studies in vivo using transgenic technology, as well as in cultured insulinoma cells engineered to respond more physiologically to glucose stimulation. In this respect the relationships between the effects of the variant insulin promoter on insulin production and glucose-stimulated insulin secretion in the patients may be more readily appreciated.

The human insulin promoter is transcriptionally active in rodent insulinoma cells (29-31) and in transgenic mice (32, 33). An insulin promoter-chloramphenicol acetyltransferase reporter transfection experiment showed that $879 \mathrm{bp}$ of 5 flanking DNA conferred tissue specific expression in insulinoma cells, whereas only sequences up to -258 were necessary for full promoter activity (31). Sequence specific binding of transcription factors was recently demonstrated with nuclear extracts from rat insulinoma cells $(29,30)$. Gel retardation and methylation-interference assays revealed specific binding with high affinity to two regions of the human insulin promoter (nucleotides -217 to -210 , and -84 to -77 ), and to a third region $(-320$ to -313$)$ with low affinity. The consensus sequence for high-affinity binding was $\mathrm{C}(\mathrm{T} / \mathrm{C}) \mathrm{CTAATG}$, while the sequence at the low affinity site -320 to -313 is GTCTAATG, differing only in the $\mathrm{G} / \mathrm{C}$ at -320 . The sequence of the insert variant, TGGTCTAATGGTCTAATG ( -330 to -313 ) contains two of the low-affinity transcription factor binding sites, versus one binding site in the normal allele. Gel retardation assays with oligonucleotides containing the repeat region showed additional high molecular weight retarded species relative to that with the normal allele (Andrew Clark and Kevin Docherty, unpublished observations). Whether these differences correspond to differences in transcription of the insulin gene in vivo, however, has not been determined.

Previous studies of the insulin gene in populations of subjects and in families with NIDDM led to the conclusion that this locus did not contribute in a major way to the inherited risk for NIDDM in any racial group $(4,5,7,8)$. The results of the current study at least partially explain failure to find an association of this locus with NIDDM in American Blacks. In the current study screening the promoter region of 100 NIDDM patients by direct genomic analysis revealed a variant in a relatively small number $(5 \%)$ which may contribute to the 
diabetes phenotype. This small number of variants would not have been detected by traditional RFLP analysis. Subsequent to the current analysis, additional SSCP analysis of the coding regions of the insulin gene from these patients revealed only silent mutations or variants within introns (manuscript in preparation).

The clinical significance of the presence of a variant insulin promoter is that it may serve as a genetic marker for NIDDM in Blacks. The observations of the presence of the variant in 1 of 100 nondiabetic American Black individuals, and the absence of the variant in 95 of 100 NIDDM patients, are entirely consistent with predictions in a multifactorial disease (34). A single gene defect is neither sufficient, nor necessary for the occurrence of the disease. It might be mentioned in this context that uncommon variations of potential but unproven significance have also been described in the insulin receptor (35) and muscle/adipose tissue glucose transporter (GLUT-4) (36) genes of NIDDM subjects. For the insulin gene, the frequency of the variant in Mauritius Creoles and American Blacks suggests there may be an association with NIDDM. These data, along with the suggestion that the variant has diminished promoter activity in cultured insulinoma cells, suggest that the variant insulin promoter increases the risk of developing NIDDM, perhaps through impaired insulin biosynthesis at the transcriptional level. This hypothesis remains to be tested.

\section{Acknowledgments}

The authors wish to thank Drs. Ken Chiu and Janet McGill for their assistance in collecting American Black DNA, and Dr. Clifton Bogardus (National Institutes of Health, Phoenix, AZ) for DNA from Pima Indians. We also wish to thank Dr. Glenn Wilson (University of South Alabama, Mobile, AL) for $\beta \mathrm{TCl}$ cells, Dr. Larry Moss (Baylor University Medical School, Houston, TX) for HIT cells, Andrew Clark and Kevin Docherty (Queen Elizabeth Hospital, Birmingham, England) for performing gel mobility shift assays, and Jeannie Wokurka for help in preparing the manuscript.

This work was supported by National Institutes of Health grant DK16746 (Dr. Permutt), and VA Research Funds (Dr. Giddings).

\section{References}

1. Haneda, M., K. S. Polonsky, R. M. Bergenstal, et al. 1984. Familial hyperinsulinemia due to a structurally abnormal insulin: definition of a new merging new clinical syndrome. N. Engl. J. Med. 310:1288-1294.

2. Porte, D., Jr. 1991. Banting lecture 1990: Beta-cells in type II diabetes mellitus. Diabetes. 40:166-180.

3. Bell, G. I., M. J. Selby, and W. J. Rutter. 1982. The highly polymorphic region adjacent to the $5^{\prime}$ end of the human insulin gene. Proc. Natl. Acad. Sci. USA. 78:5759-5763.

4. Permutt, M. A., and S. C. Elbein. 1990. Insulin gene in diabetes: analysis through RFLP. Diabetes Care. 13:364-374.

5. Andreone, T., S. Fajans, P. Rotwein, M. Skolnick, and M. A. Permutt. 1985. Insulin gene analysis in a family with maturity onset diabetes of the young. Diabetes. 34:108-114.

6. Fajans, S. S. 1990. Scope and heterogeneous nature of MODY. Diabetes Care. 13:49-64.

7. Elbein, S. C., L. Corsetti, D. Goldgar, M. Skolnick, and M. A. Permutt. 1988. Insulin gene linkage in familial NIDDM: lack of linkage in Utah Mormon pedigrees. Diabetes. 37:569-576.

8. Cox, N. J., P. A. Epstein, and R. S. Spielman. 1989. Linkage studies on NIDDM and the insulin and insulin-receptor genes. Diabetes. 38:653-658.

9. O'Rahilly, S., J. S. Wainscoat, and R. C. Turner. 1988. Type 2 (non-insulindependent) diabetes mellitus. New genetics for old nightmares. Diabetologia. 31:407-414.

10. O'Rahilly, S., R. S. Spivey, R. R. Holmann, Z. Nugent, A. Clark, and R. C. Turner. 1987. Type II diabetes of early onset: a distinct clinical and genetic syndrome? Br. Med. J. 294:923-928.

11. Permutt, M. A. 1991. The use of DNA polymorphisms for genetic analysis of non-insulin dependent diabetes mellitus. In The Genetics of Diabetes Part II. B. D. Tait and L. C. Harrison, editors. Balliere Tindall, London. 495-526.
12. Orita, M., Y. Suzuki, T. Sekiya, and K. Hayashi. 1989. Rapid and sensitive detection of point mutations and DNA polymorphisms using the polymerase chain reaction. Genomics. 5:874-879.

13. Orita, M., H. Iwahana, H. Kanazawa, K. Hayashi, and T. Sekiya. 1989. Detection of polymorphisms of human DNA by gel electrophoresis as singlestrand conformation polymorphisms. Proc. Natl. Acad. Sci. USA. 86:2766-2770.

14. Dowse, G. K., H. Gareeboo, P. Z. Zimmet, K. G. M. M. Alberti, J. Tuomilehto, D. Fareed, L. G. Brossonnette, and C. F. Finch. 1990. High prevalence of NIDDM and impaired glucose tolerance in Indian, Creole, and Chinese Mauritians. Diabetes. 39:390-396.

15. Innis, M. A., D. H. Gelfand, J. J. Sninsky, and T. J. White. 1990. PCR Protocols. A Guide to Methods and Applications. Academic Press, Inc., San Diego, CA.

16. Maniatis, T., E. F. Fritsch, and J. Sambrook. 1989. Molecular Cloning: A Laboratory Manual. 2nd edition. Cold Spring Harbor Laboratory, Cold Spring Harbor, NY.

17. Matsutani, A., R. Janssen, H. Donis-Keller, and M. A. Permutt. 1992. A polymorphic $(C A)_{n}$ repeat element maps the human glucokinase GCK (E.C12.7.1.2) gene to chromosome 7p. Genomics. 12:319-325.

18. Efrat, S., S. Linde, H. Kofod, D. Spector, M. Delannoy, S. Grant, D. Hanahan, and S. Baekkeskov. 1988. Beta-cell lines derived from transgenic mice expressing a hybrid insulin gene-oncogene. Proc. Natl. Acad. Sci. USA. 85:90379041.

19. Kazuyuki, K., and E. H. Leiter. 1990. Comparison of cytokine effects on mouse pancreatic $\alpha$-cell and $\beta$-cell lines. Viability, secretory function, and MHC antigen expression. Diabetes. 39:415-425.

20. Santerre, R. F., R. A. Cook, R. M. D. Crisel, J. D. Sharp, R. J. Schmidt, D. C. Williams, and C. P. Wilson. 1981. Insulin synthesis in a clonal cell line of simian virus 40-transformed hamster pancreatic beta cells. Proc. Natl. Acad. Sci. USA. 78:4339-4343.

21. Chen, C., and H. Okayama. 1987. High efficiency transformation of mammalian cells by plasmid DNA. Mol. Cell. Biol. 7:2745-2752.

22. DeWet, J. R., K. V., Wood, M. DeLuca, D. R. Helinski, and S. Subramani. 1987. Firefly luciferase gene: Structure and expression in mammalian cells. Mol. Cell. Biol. 7:725-737.

23. King, D. S., G. P. Dalsky, W. E. Clutter, D. A. Young, M. A. Staten, P. E. Cryer, and J. O. Holloszy. 1988. Effects of lack of exercise on insulin secretion and action in trained subjects. Am. J. Physiol. 254:E537-E542.

24. Elbein, S. C., L. Corsetti, and M. A. Permutt. 1985. New polymorphisms at the insulin locus increase its usefulness as a genetic marker. Diabetes. 34:11391144.

25. Permutt, M. A., K. Kakita, P. Malinas, I. Karl, G. C. Bonner-Weier, and S. J. Giddings. 1984. An in vivo analysis of pancreatic protein and insulin biosynthesis in a rat model for non-insulin-dependent diabetes. J. Clin. Invest. 73:1-7.

26. Leiter, E. H., M. Prochazka, D. L. Coleman, D. V. Serreze, and L. D. Shultz. 1986. Genetic factors predisposing to diabetes susceptibility in mice. In The Immunology of Diabetes Mellitus. G. D. Mollnar and M. A. Jaworski, editors. Elsevier, Amsterdam. 29-36.

27. Kaku, K., M. Province, and M. A. Permutt. 1989. Genetic analysis of obesity-induced diabetes associated with a limited capacity to synthesize insulin in C57BL/KS mice: evidence for polygenic control. Diabetologia. 32:636-643.

28. Adams, J., and R. H. Ward. 1973. Admixture studies and the detection of selection. Science (Wash. DC). 180:1137-1143.

29. Boam, D. S. W., A. R. Clark, and K. Docherty. 1990. Positive and negative regulation of the human insulin gene by multiple trans-acting factors. J. Biol. Chem. 265:8285-8296.

30. Boam, D. S. W., and K. Docherty. 1989. A tissue-specific nuclear factor binds to multiple sites in the human insulin-gene enhancer. Biochem. J. 264:233239.

31. Walker, M. D., T. Edlund, A. M. Boulet, and W. J. Rutter. 1983. Cell-specific expression controlled by the $5^{\prime}$-flanking region of insulin and chymotrypsin genes. Nature (Lond.). 306:557-561.

32. Fromont-Racine, M., D. Bucchini, O. Madsen, P. Desbois, S. Linde, J. H Nielsen, C. Saulnier, M-A. Ripoche, J. Jami, and R. Pictet. 1990. Effect of 5'flanking sequence deletions on expression of the human insulin gene in transgenic mice. Mol. Endocrinol. 4:669-677.

33. Selden, R. F., M. J. Skoskiewicz, K. B. Howie, P. S. Russell, and H. M. Goodman. 1986. Regulation of human insulin gene expression in transgenic mice. Nature (Lond.). 321:525-528.

34. Lander, E. S., and D. Botstein. 1986. Strategies for studying heterogeneous genetic traits in humans by using a linkage map of restriction fragment length polymorphisms. Proc. Natl. Acad. Sci. USA. 83:7353-7357.

35. O'Rahilly, S., W. H. Choi, P. Patel, R. C. Turner, J. S. Flier, and D. E. Moller. 1991. Detection of mutations in insulin-receptor gene in NIDDM patients by analysis of single-stranded conformation polymorphisms. Diabetes. 40:777-782.

36. Kusari, J., J. B. Buse, R. R. Henry, and J. M. Olefsky. 1991. Analysis of the gene sequences of the insulin receptor in the insulin-sensitive glucose transporter (GLUT-4) in patients with common-type non-insulin-dependent diabetes mellitus. J. Clin. Invest. 88:1323-1330. 